\title{
History and the Treaty of Waitangi Settlement Process
}

\author{
THERESE CROCKER
}

\begin{abstract}
For the past quarter of a century the New Zealand government has actively sought to negotiate and settle historical Treaty claims, and it is anticipated that the vast majority of these historical claims will be settled by 2017. The negotiation of a claim culminates in a deed of settlement signed by a Māori claimant group and the Crown, which signals the resolution of all historical grievances between a Māori claimant group and the Crown. This article offers an introductory review of the Treaty of Waitangi negotiation and settlement process and the role of historical research. Much of the work done by historians remains hidden from view and is not easily analysed, but the Crown apology is an exception: it is a tangible, publicly available outcome of the process of negotiations between a particular Māori claimant group and the Crown. In conclusion, the article provides some preliminary discussion on the role of public education in relation to Treaty of Waitangi claims negotiations and suggests that greater attention to the Crown apology would enhance public understanding.
\end{abstract}

\section{History and the Treaty of Waitangi Settlement Process}

For the past twenty-five years Māori and the Crown have engaged in negotiations to settle historical Māori grievances through the Treaty of Waitangi settlement process. History and historical research form an essential, integral component of this process, and historians working for both Iwi and Crown are engaged in a specialised form of history and contribute to a growing branch of historiography in Aotearoa/New Zealand. Yet much of the historical material generated and the practitioners who produce it remain unseen and the emerging historical research is a frequently overlooked source for many outside of the 'Treaty industry' itself. During the past three decades significant expertise and resources have been allocated to historical research, yet for the most part this historical material is not easily accessed or analysed. ${ }^{1}$ The published Waitangi Tribunal reports are an obvious exception to this. As the number of claims researched for Waitangi Tribunal inquiries continues to grow, along with the number of negotiated Treaty of Waitangi settlements between Māori and the Crown, there is a growing body of available work to be considered and analysed by historians.

This article is a brief introduction to the role of history in the Treaty of Waitangi settlement process, and to the history that is emerging from these processes. It was anticipated that that a flow-on effect of the Treaty of Waitangi settlement process would be an increase in the public's understanding of Treaty of Waitangi issues. However, there have been hurdles to informing the public about the background of historical Treaty of Waitangi claims and the reasons for establishing the process of negotiations. ${ }^{2}$ This has resulted in a specific conundrum: while public resources have been extensively deployed to investigate historical events of national importance, comparatively little public history has emerged from the process. One of the goals of public history is to present the past in ways that are relevant and more accessible to a wider, non-specialist audience. Of course, there is an inherent tension, faced by successive governments, between educating the public and trying to impose the official view on them. Nonetheless, the Crown apology is an example of an agreed historical text between Māori and the Crown and could play a much greater role informing the public about the past. ${ }^{3}$ 


\section{Public history in New Zealand}

Public History has broadly been identified as work that is undertaken outside the academy that nonetheless adheres to the standards of the historical discipline. In the New Zealand context, Bronwyn Dalley has argued that our "public history community shares one important common feature: its members work to the agendas, research priorities, or the funding capacity of another party rather than selecting their own research topic." ${ }_{4}^{4}$ However, there is still quite a degree of overlap between historians in academia and those working in the field of public history. Historians employed in the Treaty of Waitangi settlements sector tend to draw on their academic training and largely employ the same methodological approaches as their academic colleagues. Given the relatively small pool of historians in New Zealand, some historians primarily employed in academia may also be engaged in the Treaty of Waitangi settlements process. But participation in a legal process such as this brings to the fore another dimension of public history: the need for a "usable past."

When reflecting on the increasing role of historians presenting evidence before the Waitangi Tribunal, Alan Ward drew attention to the changing approaches to historical methodology and practice as historians adjusted to appearing as expert witnesses. ${ }^{6}$ Historians were being asked to apply their discipline outside the lecture room in a quasi-legal process, where their work was critiqued and cross-examined before the Waitangi Tribunal. McHugh has argued that "within this context the writing of history is a politically charged exercise, where the pressure to service the needs of the present is felt as strongly as any inclination towards preservation of the integrity of the past." I will now turn to briefly outline the settlement process.

\section{The Treaty of Waitangi claims settlement process}

The Treaty of Waitangi, recognised as New Zealand's founding document, was signed on 6 February 1840 between representatives of the British Crown and Māori. The Māori version of the Treaty guaranteed that Māori could retain their lands, forests and fisheries for as long as they wished. However, as settlers arrived and pressure for land grew, the government began to acquire land in ways that breached the Treaty. Over time, the vast majority of Māori land was alienated through actions such as the Crown purchase of Māori land for low prices, that left Māori with inadequate land reserves; the confiscation of land following the New Zealand wars; and the consequences of the Native Land Laws. Although Māori sought recognition of these Treaty breaches from the time they occurred, it was not until the period of the Māori renaissance in the 1960s and 1970s that calls for the Crown to honour the Treaty were addressed. As a result the Waitangi Tribunal was established as a permanent commission of inquiry in 1975. It could inquire into actions and omissions of the Crown that were "inconsistent with the principles of the Treaty" from 1975 onwards. ${ }^{8}$ Further political pressure resulted in the 1985 Treaty of Waitangi Amendment Act which extended the historical time frame, and enabled the Tribunal to inquire into whether Maori were prejudicially affected by any actions, omissions, legislation, or policies of the Crown that were inconsistent with the principles of the Treaty of Waitangi from the time of the signing of the Treaty. This enabled Māori, either individually or collectively, to register a claim with the Waitangi Tribunal. ${ }^{9}$ The 1985 amendment to the Treaty of Waitangi Act also provided unprecedented opportunities for professional historians outside the academy. Historical Treaty of Waitangi claims are settled through negotiations between the claimants and the Crown. ${ }^{10}$

All claims must first be registered with the Waitangi Tribunal. Once a claim is registered with the Waitangi Tribunal claimants are able to choose whether to have their claims inquired into by the Waitangi Tribunal (resulting in a published Waitangi Tribunal report) or progress their claims through the process of direct negotiations with the Crown. During the 
process of negotiations, the Office of Treaty Settlements (OTS) represents the executive arm of government in the process of negotiations between a particular claimant group and the Crown and reports to Cabinet for approval. The Office of Treaty Settlements was established in 1995 (as successor to the Treaty of Waitangi Policy Unit) to coordinate the direct negotiations of historical claims, provide policy advice to the Minister for Treaty of Waitangi Negotiations, and implement the resulting settlements. ${ }^{11}$ Claimants with a registered claim can also choose to move into negotiations with the Crown at any stage of the Waitangi Tribunal inquiry process.

The Waitangi Tribunal generally seeks to hear claims within a geographical area or inquiry district at the same time. ${ }^{12}$ A sufficient level of research to identify the key issues and events in the inquiry district must be prepared before the Tribunal is able to proceed with its hearings. This usually requires historical investigation into the details of claims in a particular inquiry district. There are a number of ways this historical research can be carried out: claimants can complete their own research or the Waitangi Tribunal can commission research to be undertaken (either by its own research staff or by an independent contract historian). Claimants can also access funding and expertise through the Crown Forestry Rental Trust. Established in 1989 under the Crown Forest Assets Act 1989, the Crown Forestry Rental Trust (CFRT) holds the licence fees paid for the rental of Crown forest land. Interest from the licence fees is used to "assist Māori to prepare, present and negotiate claims against the Crown" over an entire inquiry district, which might include some Crown forest licensed lands. ${ }^{13}$ The Crown Forestry Rental Trust works with claimants and the Waitangi Tribunal or the Office of Treaty Settlements to develop a research plan for claims or groups of claims that involve (or could involve) Crown forest land. The Crown Forestry Rental Trust employs some historians inhouse and commissions others to undertake the agreed historical research. Historians who work for (or are contracted to) the Waitangi Tribunal and Crown Forestry Rental Trust undertake primary research in historical material relating to a claim; they prepare a report based on their research and then present their evidence to a Waitangi Tribunal as expert witnesses. ${ }^{14}$

As indicated earlier, claimants can approach the Office of Treaty Settlements for direct negotiations with the Crown at any stage in the process. ${ }^{15}$ Claims that have been heard by the Waitangi Tribunal also progress to the Office of Treaty Settlements for resolution through the negotiations process. The outcome of a negotiation is a deed of settlement signed between a claimant group and the Crown, signalling the resolution of historical grievances between that group and the Crown. The Office of Treaty Settlements employs historians whose roles include the assessment of historical research in preparation for direct negotiations and the negotiation of the Crown apology. The Crown Law Office is also involved in the Treaty of Waitangi claims settlement process. Crown Law represents the Crown at Waitangi Tribunal hearings and provides advice to the Office of Treaty Settlements in the direct negotiations process, and contracts historians to assist with this role.

Examination of historical practices and outcomes in the Treaty of Waitangi claims process to date has tended to focus on Waitangi Tribunal inquiries, reports, and the role of historians within that process. ${ }^{16}$ This is hardly surprising, given the significance and public availability of the Waitangi Tribunal reports. I would like to suggest that 25 years since the establishment of the Treaty of Waitangi claims settlement process, it is time we shifted our gaze to analyse the role of history in the entire Treaty of Waitangi settlement process, including the settlements themselves. There is much here that merits closer consideration and scrutiny. This potentially contested area, where Māori and the Crown interact and where history and policy meet, is ripe for reflection. The current disregard of the role of history in the direct negotiation process is perhaps understandable given that Waitangi Tribunal Reports are published and readily available in the public domain, while the Treaty settlements negotiation 
process is essentially a confidential process between Crown and claimant group. ${ }^{17}$ There is a substantial amount of detailed historical material and research generated by the Treaty of Waitangi claims commissioned by the Waitangi Tribunal, the Crown Forestry Rental Trust and the Crown Law Office, which is not readily available for analysis and consideration. Much of this material exists as grey literature in the process; it sits on the shelves and in the hard drives of those involved but is not readily available to those outside the Treaty of Waitangi settlement arena. Richard Boast advocates that this material prepared for the Waitangi Tribunal inquiries should be digitized and be available to the public, particularly given the amount of "effort, time and resources that have been poured into the process." 18 A good place to begin this analysis might be with the Crown apology.

\section{The Crown apology as public history}

An example of accessible public history that has emerged since the mid-1990s from the Treaty of Waitangi Settlement negotiation process is that of the Crown apology. The Crown apology has come to form a key part of the process of direct negotiations between a Māori claimant group and the Crown, which culminates in the signing of a deed of settlement between the two parties. Historians who work for the Office of Treaty Settlements (and other Crown representatives as needed) negotiate with Māori claimants to produce the Crown apology. ${ }^{19}$ These historians fit the definition of public historians as articulated by Dalley: they work to agendas, research priorities and funding that are not self-selected. The history they produce plays a significant role in the settlement of Treaty of Waitangi claims, yet to date it has not been closely analysed by those writing about the Treaty of Waitangi claims settlement process.

A deed of settlement negotiated between the claimant representatives and the Crown is the goal of the Treaty of Waitangi claims negotiation process, and it signifies the resolution of all historical claims for a defined group over a defined geographical area. It includes fiscal or commercial redress, cultural redress, and a Crown apology negotiated between the claimant group and the Crown. There are three elements in the historical component of a deed of settlement: an historical account, the Crown acknowledgements and the Crown apology itself. ${ }^{20}$

Within the process of negotiations between claimants and the Crown dedicated working groups are formed to meet regularly to negotiate on specific aspects of a settlement, such as fiscal (or commercial) reparation, cultural redress, and the Crown apology. The configuration for each negotiations process will differ slightly. Claimant negotiators select those who will best represent them on the Crown apology working group; often it may be mandated claimant negotiators plus kaumātua, kuia, legal counsel, and any other experts they choose. ${ }^{21}$ Since about 2006 there has been an increased use of contract historians on claimant negotiation teams. There is a large variation in the size and makeup of claimant representatives at the negotiations table; for some claims it will be a large group, comprising claimants, lawyers, and historians, while only one or two individuals may represent others. The Crown team generally consists of Historians from the Office of Treaty Settlements and counsel from the Crown Law Office. Other representatives of government departments may be brought in as necessary. As well as variation of personnel around the table, there is variation in the length of time taken for the negotiations themselves. Some historical accounts may be agreed in a few weeks, while others take years of meetings and discussions. There is often a larger context to any delays in producing an historical account, as for example if the wider negotiations have slowed or stalled. At other times it may be politically expedient to move forward with a settlement, and it has been noted that progress on Treaty settlements generally increases in an election year. ${ }^{22}$ 
The negotiating parties begin with a broad understanding of the outline of the claim and potential Crown breaches of the Treaty, and they may have a Waitangi Tribunal report which provides historical details of the claim. But it still requires a great deal of dialogue and understanding to work through to the detail necessary to get to an agreed version of events and a meaningful apology. For many claimants, who have not been through a Waitangi Tribunal inquiry process, this may be the first time they have had the opportunity to personally describe the impact of historical Crown actions to representatives of the Crown. The working group meet regularly to discuss how to approach the historical account, to draft wording and debate meaning. Following this, the Crown acknowledgements and Crown apology are negotiated. The negotiations are conducted confidentially between representatives of a claimant group and representatives of the Crown until a consensus is reached and a draft deed of settlement is presented to the wider claimant group for their consideration and ratification.

The historical account is an agreed negotiated text between the Crown and a claimant group, and narrates the factual background to historical events that have caused grievance for that group. The emerging historical account is thereby a multi-authored outcome of a negotiated process. The length of the historical account varies: existing examples are between about three and 25 pages in length. The first time a historical account appeared in a deed of settlement as a discrete component was in the Te Uri o Hau Deed of Settlement in 2000. ${ }^{23}$ In that example the historical account is written in Māori and translated into English in the deed of settlement. Another example is the Ngaruahine Deed of Settlement, signed in August 2014. The historical account is detailed, at 22 pages long, and includes images and maps to support the written evidence. ${ }^{24}$

The historical account informs the Crown acknowledgements. The acknowledgements set out the breaches of the Treaty of Waitangi and its principles, and other Crown actions that have caused harm or grievance. Details of the consequences of the breaches including landlessness and social impacts are also included in the historical acknowledgements. As an example the Crown Apology to Ngaruahine states:

The Crown acknowledges that recognition of the historical grievances of Ngaruahine is long overdue. The Crown hereby recognises the legitimacy of the grievances of Ngaruahine and makes the following acknowledgements. ${ }^{25}$

For example, the historical acknowledgements recognise the ongoing impact of ruaptau (confiscation of land) on Ngaruahine:

The people of Ngaruahine have suffered from the effects of poverty, poor housing and degraded physical and spiritual health. Ngaruahine have been unable to develop a strong economic base, and the unemployment rate among Ngaruahine is more than double the national average.

The Crown also acknowledged and apologised for actions that had led to the outbreak of the Taranaki war, for attacks against Ngaruahine kainga or villages, and the use of scorched earth tactics. "These actions caused severe hardship, deprivation, exile and death for many of your people." 26

The Crown then makes an explicit statement of regret for those recognised injustices and apologises to the claimant group. A Crown apology attempts to recognise the impact of the breaches on the claimant group, restore the honour of the Crown, and begin to re-build the relationship between the Crown and the claimant group. ${ }^{27}$ The Crown apology is often given by the Minister in Charge of Treaty Settlements in public at the time of the signing of a Deed of Settlement. For many members of the public this gesture is one of the most obvious and tangible aspects of the Treaty of Waitangi settlements process. Unlike much of the Treaty of 
Waitangi negotiations process, the signing of a Deed of Settlement is usually a public ceremony attended by the claimant group and representatives of the government. By mid 2014 over 60 deeds of settlement had been signed between Māori claimant groups and the Crown. ${ }^{28}$ Those claims that have not yet been settled are in various stages of the negotiations process.

Crown apologies have evolved significantly over the years. The first public Crown apology was part of the Waikato Deed of Settlement signed in May 1995. Sir Douglas Graham, Minister in Charge of Treaty Negotiations at the time, supported the principle of an apology from the Crown. He was concerned that a settlement based solely on the return of assets or payment of money would not address a sense of grievance. He recalled,

It was suggested therefore that the Crown should formally acknowledge the wrong done and tender a full apology. Only then was it possible to put the sad events of history into their proper place - not forgotten but accepted. ${ }^{29}$

The details of the Crown apology were negotiated between representatives of Tainui and Crown officials. Queen Elizabeth II personally assented to the legislation giving effect to the settlement, the Waikato Raupatu Claims Settlement Act 1995, which included the apology to Waikato-Tainui, redress to the value of $\$ 170$ million and the return of Crown land confiscated in the 1860s. The detail and length of the Crown apology for Waikato-Tainui was briefer than the current apologies tend to be, and recent historical accounts are regularly over 10,000 words ${ }^{30}$ In a study of historical accounts from 48 Deeds of Settlement signed between 1993 and 2011, David Haines noted considerable change over the period, "both in the type of content included, and more fundamentally, in the sheer amount of detail covered." 31 This is a sign of an evolving process, one that takes into account the requirements and priorities of a claimant group themselves. It also potentially reflects a growing international trend, that of historical examination as a tool for reconciliation. The New Zealand experience can be seen in a wider context of Western nations coming to terms with their colonial past, in what has been labelled the "age of the apology." 32 Contemporary western societies seek to confront and reconcile the past in the present. Public apologies can make a contribution to this process "toward reconciliation between indigenous peoples and settler populations... [and] in our nation's coming to terms with its colonial past." 33 Maureen Hickey, writing as a historian at the Office of Treaty Settlements, observed that the negotiations process compels the Crown to confront historical actions and grievances it has created:

a record of history, albeit in a relatively brief summary form, [that] puts the Crown in the position of having to remember and accept responsibility for the failures of the past. The joint drafting process is itself an act of reconciliation as inevitably both sides have to reconcile some divergent perspectives to arrive at a shared history. ${ }^{34}$

Deeds of Settlement are generally implemented by settlement legislation and the historical acknowledgements and Crown apology are also set out in the legislation. The historical account tends to be summarised in the preamble of settlement legislation, which gives legal effect to a deed of settlement.

The process of negotiating the historical account and Crown apology is not without its shortcomings. Rachel Buchanan points out that while academics tend to be celebratory about Crown apologies this is not necessarily the experience for Māori who may experience "indifference, anger or even disdain." Buchanan argues, for example, that a series of apologies from the Crown for its 1881 invasion and ransacking of Parihaka, demonstrates a "mismatch between the responses of the givers and the receivers." ${ }^{35}$ There is potential for tension between the Crown and a claimant group from the beginning as they sit down to work towards an agreed 
statement of facts for a claim (and tensions do exist). ${ }^{36}$ A claimant group may well have a different interpretation of historical events to that of the Crown. And at times, where agreement on a particular issue cannot be reached, the text may indicate that the point of view of the claimant group is not endorsed by the Crown. An example of this can be found in the Historical Account in the Tūhoe Deed of Settlement:

Tūhoe maintain they have interests in 124,300 acres of the confiscated land. The confiscated land included the bulk of Tūhoe's most productive cropping and agricultural lands, as well as the kāinga they occupied at Ōhiwa. Other iwi shared interests in this land. ${ }^{37}$

There is no doubt that these negotiations are carried out within certain political parameters. Ultimately the decision of whether to accept the wording rests with the claimant group, which must endorse every aspect of a Deed of Settlement before it is ratified and becomes binding.

\section{Where are the public in this public history?}

As was suggested earlier, the Crown apology may perform an important role in contemporary New Zealand society; that of explaining to the public the reasons why historical settlements are being negotiated. Emma Wethey argues that where a historical background introduces an apology offered by the state it forms an important part of the historical and public record, and "through this means such a history forms an educative function within an apology and promotes reconciliation through informing the public of unjust acts and their impacts." 38 Although the primary audience for a Crown apology are the claimant group themselves, the public are able to, and should be encouraged to, access and engage with this history. Details of Treaty of Waitangi settlements, complete with the text of the Crown apology, are released at the time of the signing of the deed of settlement. ${ }^{39}$ In the main, the work of Treaty of Waitangi negotiations and settlements is carried out under the cautious acceptance and, at times, hostility from sections of the public. This might be in part because there is little room for the public to participate; the nature of the negotiations requires confidentiality for both parties during the process.

Public education around Treaty of Waitangi issues has proved problematic for successive governments. While the goal of informing the public of the background to historical Treaty of Waitangi grievances and the approaches to resolving these claims may be a reasonable one, there is a fine line between education and coercion. Bringing the public onboard with the reasons for addressing historical Treaty of Waitangi settlements was favoured in the early years of the Treaty of Waitangi settlements process. Sir Douglas Graham, as the first Minister in Charge of Treaty of Waitangi Negotiations reflected, "I have no doubt that New Zealanders are fair-minded people. The tragedy is that so few know the facts and they cannot be blamed for that." ${ }^{40}$ It was his view that if New Zealanders knew their history they would understand what the government was trying to achieve in the settlement of historical grievances and as a result, support the process. Graham addressed many groups, including Rotary clubs, rural and special interest groups, explaining the background to Treaty of Waitangi claims and the National party's motivations for wanting to settle claims.

Early in 1996 the National government was considering a campaign to improve public understanding of issues which arise from the Treaty of Waitangi. As no progress had been made on this by March 1996 it was decided to defer any decisions until May 1997 to avoid the perception that the government was trying to influence public opinion close to a general election. The issue of public education re-emerged as a Labour-led Coalition government came to power following the general election in November 1999. The Labour party had campaigned 
on a Treaty education policy and Margaret Wilson, as Treaty Negotiations Minister, proposed hosting a series of "town hall meetings" aimed mainly at Pākehā New Zealand to discuss the historical Treaty settlement processes..$^{41}$ The co-ordinating Minister of Race Relations, Trevor Mallard, later took over this role. The opposition spokesperson, National's Murray McCully, promised to take a hard look at the project to see whether Mallard would "bring at last some common sense to this area and eradicate the political correctness that drives the bureaucrats and ministers." ${ }^{42}$

The Labour-led Coalition's plans for Treaty education and the continuation of policies on "Closing the Gaps" between Māori and non-Māori were subsequently curbed following the groundswell of support for National's "one law for all" approach. ${ }^{43}$ In an address to the Orewa Rotary Club in January 2004, National Party Leader Don Brash criticised the race-based approach to the "Closing the Gaps" policies, claiming they would lead to division within New Zealand. Brash advocated that special treatment should not be provided on racial grounds, and he echoed the mantra of one rule for all New Zealanders. ${ }^{44}$ The attention garnered by Brash's speech led to a change in approach by the Labour-led coalition and their policy focus on Treaty settlements shifted from an "education" to an "information" programme. ${ }^{15}$ This information programme, led by the Treaty of Waitangi Information Unit, part of the State Services Commission, included the launch of a website in April 2004 and a mobile exhibition "Treaty 2 U" in January $2006 .{ }^{46}$ The exhibition travelled to over 35 cities and towns throughout the country. In 2009 a variation of the exhibition opened at Te Papa. ${ }^{47}$ The Treaty of Waitangi information unit was only operational for a short period, although the State Services Commission maintained the information website for some time. ${ }^{48}$ While the National-led coalition Government (elected in 2011) has accelerated progress on the settlement of historical Treaty of Waitangi, it does not appear that Treaty of Waitangi education or information has the priority it had a decade ago. ${ }^{49}$

\section{Conclusion}

The Treaty of Waitangi claims settlement process has generated renewed interest in New Zealand history. The Waitangi Tribunal has to date published 118 reports, many of these focussed on historical actions or omissions of the Crown. It is now over a quarter of a century since the Crown and Māori began the process of direct negotiations for the settlement of historical grievances. In that period the negotiation process has evolved to include a detailed historical account, Crown acknowledgements and Crown apology which are included in a deed of settlement between a specific Māori claimant group and the Crown. An outcome of the Waitangi Tribunal inquiries and the Treaty of Waitangi settlement process has been the substantial body of historical material commissioned to inform these processes. Further work is required to make this material more readily available for assessment and analysis, but the Crown apology, the outcome of a negotiated process between claimant groups and the Crown, should be given much greater public prominence. The apology plays a significant role as a reconciliation tool in the settlement of historical grievances, and is an important example of public history.

The role of education in the Treaty of Waitangi Settlement process has proved somewhat problematic for governments. Previously, there was a desire to get public endorsement for the settlement of historical Treaty of Waitangi claims, but in recent years central government appears to have put less emphasis on public education about the Treaty of Waitangi settlement process and more on negotiating with Māori to achieve settlements. The Crown apology is emerging as an essential component of the whole process of negotiations between a particular claimant group and the Crown. The modification of Crown apologies over time points to an evolving practice, one that better reflects a shared acknowledgement of the 
past in the present. With this in mind, perhaps more attention should be placed on bringing Crown apologies into the public realm.

${ }^{1}$ The 1985 Treaty of Waitangi Amendment Act provided for the Waitangi Tribunal to hear claims dating back to 6 February 1840. This is discussed in more detail below. Pioneering negotiations between The Treaty of Waitangi Policy Unit (TOWPU) and Waikato-Tainui began in 1989.

${ }^{2}$ In this paper, I differentiate between the two avenues to settling a claim, "direct negotiations" and "negotiations." The term "direct negotiations", introduced in 1989, refers to the process where claimants bypass the Waitangi Tribunal and take their claim directly to the Crown to negotiate a settlement. "Negotiations" indicates that a claim has been subject to a Waitangi Tribunal inquiry and then proceeds to settlement negotiations with the Crown.

${ }^{3}$ This article is a revised version of a paper presented on 20 March 2013 as part of a series on Contemporary Debates within Public History, hosted by the Stout Research Centre, Victoria University of Wellington. I would like to thank the two anonymous reviewers of an earlier version of this article.

${ }^{4}$ Bronwyn Dalley, "Finding the Common Ground," in Going Public: The Changing Face of New Zealand History, ed. Bronwyn Dalley and Jock Phillips (Auckland: Auckland University Press, 2001), 24.

${ }^{5}$ Bernard Eric Jensen, "Usable Pasts: Comparing Approaches to Popular and Public History," in People and Their Pasts: Public History Today, ed. Paul Ashton and Hilda Kean (Basingstoke: Palgrave Macmillan, 2009).

${ }^{6}$ Alan Ward, "History and Historians before the Waitangi Tribunal: Some reflections on the Ngai Tahu Claim," New Zealand Journal of History 24, no.2 (1990): 151.

${ }^{7}$ Paul McHugh, "Law, History and the Treaty of Waitangi," New Zealand of History 31, no.1 (1997): 38.

${ }^{8}$ Treaty of Waitangi Act 1975, S6(1).

${ }^{9}$ The last day for registering historical claims was 1 September 2008; Section 6 Treaty of Waitangi Amendment Act 2006.

${ }^{10}$ Although any Māori either individually or as part of a wider group can register a claim, the Crown has expressed a preference to negotiate claims with large natural groupings, such as iwi (tribes) or groups of iwi, rather than individual hapu (sub-tribe) or whānau (extended family group). Office of Treaty Settlements, Ka Tika a Muri, ka Tika à Mua; Healing the Past, Building a Future: A Guide to Treaty of Waitangi Claims and Negotiations with the Crown (Wellington, OTS, 2010), 32.

${ }^{11}$ Historical claims are defined as actions or omissions of the Crown prior to 21 September 1992. Any actions or omissions of the Crown after this date are defined as contemporary claims and are the responsibility of the relevant government department. The 21 September 1992 is the date Cabinet agreed to the programme for settlement of Treaty of Waitangi claims.

${ }^{12}$ With the exception of generic claims or claims heard under urgency. 
13 "A Mātou: About the Trust." Crown Forestry Rental Trust, accessed 30 August 2014, http://www.cfrt.org.nz/about/. For further detail on the role of Crown Forestry Rental Trust in claimant research

http://www.cfrt.org.nz/doclibrary/public/thestorehouse/publications/claimantassistancebooklet.pdf.

${ }^{14}$ In recent years, Crown Forestry Rental Trust historians have also been engaged by claimants to assist with the drafting and the negotiation of the Crown apology.

${ }^{15}$ Certain criteria must be met before formal direct negotiations can commence: see Office of Treaty Settlements, Ka Tika a Muri, 41. Recently, the Crown has indicated that it is open to a parallel Tribunal and direct negotiation process in relation to Ngāpuhi and Ngātiwai. No progress has yet been made on this parallel process, but the approach recognises that claimants want both a Tribunal hearing and to make progress on their settlement. Maureen Hickey, (Office of Treaty Settlements), Personal Communication, 16 June 2014.

${ }^{16}$ See, for example, Michael Belgrave, "Something Borrowed, Something New: History and the Waitangi Tribunal," in Going Public, ed. Dalley and Phillips (Auckland: Auckland University Press, 2001), 98-103; Giselle Byrnes, The Waitangi Tribunal and New Zealand History (Auckland: Oxford University Press, 2004); W. H. Oliver, "The Future Behind Us: The Waitangi Tribunal's Retrospective Utopia," in Histories, Power and Loss: Uses and the Past - A New Zealand Commentary, ed. Andrew Sharp and Paul McHugh (Wellington, Bridget Williams Book, 2001), 11; M. P. K Sorrenson, 'Towards a Radical Reinterpretation of New Zealand History: The Role of the Waitangi Tribunal," in Waitangi: Māori and Pākehā Perspectives on the Treaty of Waitangi, ed. I. H. Kawharu (Auckland, Oxford University Press, 1989), 159.

${ }^{17}$ Another aspect of the process that has not been critiqued in detail are the many historical research reports produced by historians acting as expert witnesses for claimants or the Crown for each Waitangi Tribunal inquiry.

${ }^{18}$ Richard Boast, "New Zealand Legal History and New Zealand Historians," Journal of New Zealand Studies, 9 (2010): 30.

${ }^{19}$ The author was employed as a historian at the Treaty of Waitangi Policy Unit (subsequently known as the Office of Treaty Settlements) from 1994-1998 and continued to work as a contract historian from 1998-2011.

${ }^{20}$ The generic term "Crown Apology" is sometimes used to encompass all three of these elements. See Office of Treaty Settlements, Ka Tika à Muri, 85.

${ }^{21}$ Kaumātua is defined as an elderly man or man of status within a kinship group; Kuia is defined as elderly woman or woman of status within a kinship group.

${ }^{22}$ Dean Cowie, "The Treaty Settlement Process," in Treaty of Waitangi Settlements, ed. Nicola R. Wheen and Janine Hayward (Wellington: Bridget Williams Books, 2012), 49.

${ }^{23}$ Te Uri o Hau Deed of Settlement, 13 December 2000, accessed 17 February 2014, http://nz01.terabyte.co.nz/ots/DocumentLibrary/TeUrioHau-DeedofSettlement.pdf. Prior to this historical details were included as a preamble to the Crown Apology, as in the Waikato-Tainui and Ngai Tahu Deeds of Settlement.

${ }^{24}$ Ngaruahine Deed of Settlement of Historical Claims, 1 August 2014, accessed 20 October 2014, http://nz01.terabyte.co.nz/ots/DocumentLibrary/Ngaruahine-DeedofSettlement.pdf.

${ }^{25}$ ibid.

Journal of New Zealand Studies NS18 (2014), 106-117 
${ }^{26}$ ibid.

${ }^{27}$ Office of Treaty Settlements, Ka Tika a Muri, 85 .

${ }^{28}$ Claims Progress, Office of Treaty Settlements, updated 18 June 2014. Accessed 20 June 2014, http://www.ots.govt.nz.

${ }^{29}$ Douglas Graham, Trick or Treaty (Wellington: Institute of Policy Studies, 1997), 74.

${ }^{30}$ See, for example, Ngati Tāmanahuri, Deed of Settlement 2011, accessed 17 February 2014, http://nz01.terabyte.co.nz/ots/DocumentLibrary/NgaiTamanuhiriDeedofSettlement.pdf; Ngāti Whātua o Kaipara, Deed of Settlement 2011, Office of Treaty Settlements. Accessed 17 February 2014, http://www.ots.govt.nz.

${ }^{31}$ David Haines, "Accounts Payable: The Uses of History in Treaty Settlement Negotiations" (paper presented at the New Zealand Historical Association conference, November 16 2011).

${ }^{32}$ R. E. Howard-Hassmann and M Gibney, "Introduction: Apologies and the West," in The Age of Apology: Facing up to the Past, ed. M. Gibney, R. E. Howard-Hassmann, J. Coicaud, and N. Steiner (Philadelphia: University of Pennsylvania Press, 2008), 1.

${ }^{33}$ Meredith Gibbs, "Apology and Reconciliation in New Zealand's Treaty of Waitangi Settlement Process,". in The Age of Apology, ed. Gibney, Howard-Hassmann, Coicaud, and Steiner, 154.

${ }^{34}$ Maureen Hickey,"Apologies in Settlements," in Treaty of Waitangi Settlements, ed. Wheen and Hayward, 87.

${ }^{35}$ Rachel Buchanan, "Beating Shame: Parihaka and the Very Long Sorry," Te Pouhere Kōrero, (2012): 60. See also Crown Forestry Rental Trust, Mãori Experiences of the Direct Negotiations Process (Wellington: Crown Forestry Rental Trust, 2003); Craig Coxhead, "Where are the negotiations in the Direct Negotiations of Treaty settlements?" Waikato Law Review 10 (2002): 13-38.

${ }^{36}$ See comments by Judge Joe Williams, Opotiki News, "High Court overturns decision,” June 152014.

${ }^{37}$ Historical Account, Tūhoe Deed of Settlement, para 2.24. Accessed 20 June 2014 (emphasis mine), http://nz01.terabyte.co.nz/ots/DocumentLibrary/TuhoeDOS.pdf.

${ }^{38}$ Emma Wethey, "The Politics of Apology: Issues Arising from State Apologies to Indigenous Peoples for Historical Injustices in Australasia and North America" (master's thesis, University of Cambridge, 2002), 15.

${ }^{39}$ All deeds of settlement are accessible on the website of the Office of Treaty Settlements, http://www.ots.govt.nz . Press releases are available through the Parliamentary website, http://www.beehive.govt.nz.

${ }^{40}$ Graham, Trick or Treaty, 89.

${ }^{41}$ Margaret Wilson, " $25^{\text {th }}$ Anniversary of the Waitangi Tribunal," 10 October 2000, accessed 7 March 2013, http://www.beehive.govt.nz/node/8736.

${ }^{42}$ New Zealand Herald, “Treaty Education Plan Faces 'PC' Inspection,” April 192004. 
${ }^{43}$ For an outline of the "Closing the Gaps" policy see press release by Tariana Turia 7 June 2000, accessed 17 Feburary 2014, http://www.beehive.govt.nz/speech/closing-gaps.

${ }^{44}$ For a response to Brash's speech see Ranginui Walker, Ka Whawhai Tonu Matou - Struggle Without End (Auckland: Penguin Books, 2004), 392-400.

${ }^{45}$ New Zealand Herald, “Mallard 'Safer' Bet for Treaty Role,” October 202003.

${ }^{46}$ Treaty of Waitangi information unit. Accessed 17 February 2014,

http://www.treatyofwaitangi.govt.nz; New Zealand Herald, April 19 2004;

http://www.beehive.govt.nz/release/treaty-waitangi-website-launched, 19 April 2004, accessed 17

February 2014.

${ }^{47}$ Robert Consedine, "Anti-Racism and Treaty of Waitangi Activism - Government and Community Anti-Racism Organisations," Te Ara - the Encyclopedia of New Zealand, updated 16-Nov-12, accessed 20 June 2014, http://www.TeAra.govt.nz/en/photograph/26685/treaty-2u.

${ }^{48}$ A Māori version of the website remains online, accessed 20 June 2014, http://www.tiritiowaitangi.govt.nz/

${ }^{49}$ See Christopher Finlayson, 'Three Treaty Bills Progressed', accessed 17 June 2014, http://www.beehive.govt.nz/release/three-treaty-bills-progressed. 